DOI: $10.15193 /$ zntj/2021/127/374

\author{
KAMILA JOANNA DANILUK, MICHAŁ WÓJCICKI, \\ EDYTA JUSZCZUK-KUBIAK
}

\title{
BIOFILM BAKTERYJNY I MOŻLIWOŚCI JEGO ELIMINACJI W PRZEMYŚLE SPOŻYWCZYM
}

\begin{abstract}
Streszczenie
Biofilmy bakteryjne występujące w przemyśle spożywczym stanowią złożone, wielogatunkowe grupy zarówno bakterii saprofitycznych, jak i patogennych. Często zlokalizowane są na powierzchniach trudno dostępnych dla środków myjących stosowanych w obiegu zamkniętym, jak i dla mechanicznego czyszczenia. W przemyśle spożywczym biofilmy bakteryjne stanowią źródło zanieczyszczeń mikrobiologicznych żywności, powodując obniżenie jakości i trwałości produktów spożywczych. Ponadto biofilmy spożywcze mogą być źródłem bakterii patogennych, takich jak Salmonella spp., Campylobacter spp. czy Listeria monocytogenes oraz bakterii oportunistycznych (np. Escherichia coli), wywołujących choroby układu pokarmowego, które mogą być długotrwałe i trudne do leczenia, zwłaszcza u osób z obniżoną odpornością. W niniejszym opracowaniu przedstawiono podstawowe mechanizmy tworzenia biofilmu bakteryjnego oraz najistotniejsze funkcje pełnione przez zewnątrzkomórkową macierz biofilmu (EPS). Scharakteryzowano główne bakteryjne patogeny występujące w branżach: mięsnej, mleczarskiej, ryb i owoców morza, produktów pochodzenia roślinnego o minimalnym stopniu przetworzenia oraz w sokowniczej, z uwzględnieniem możliwości tworzenia przez te drobnoustroje biofilmu trwałego i opornego na czynniki zewnętrzne. Przedyskutowano również możliwości eradykacji biofilmów spożywczych ze szczególnym uwzględnieniem metod polegających na zastosowaniu związków naturalnych pochodzenia roślinnego oraz wykorzystaniu litycznych bakteriofagów i/lub ich oczyszczonych enzymów.
\end{abstract}

Słowa kluczowe: biofilm bakteryjny, macierz zewnątrzkomórkowa, patogeny, eliminacja biofilmu, przetwórstwo żywności

\section{Wprowadzenie}

Wzrost świadomości konsumentów, standardy jakości produktów spożywczych oraz konkurencja na rynku wpłynęły na konieczność prowadzenia ścisłej kontroli produktów, które dostarczane są do handlu, jak również monitorowanie każdego etapu

Mgr inż. K. J. Daniluk, mgr inż. M. Wójcicki, dr hab. E. Juszczuk-Kubiak, prof. IBPRS, Zakład Mikrobiologii, Instytut Biotechnologii Przemystu Rolno-Spożywczego im. Prof. W. Dąbrowskiego - Państwowy Instytut Badawczy, ul.Rakowiecka 36,02-532 Warszawa.Kontakt: michal.wojcicki@ibprs.pl 
procesu technologicznego w zakładzie produkcyjnym. W przemyśle spożywczym wypracowano procedury mycia i dezynfekcji linii produkcyjnych, które gwarantują zachowanie bezpieczeństwa mikrobiologicznego w procesie produkcyjnym [30]. Metody te są skuteczne w usuwaniu zanieczyszczeń spowodowanych przez formy planktoniczne drobnoustrojów [22]. Wciąż nierozwiązanym problemem jest tworzenie na liniach produkcyjnych, zwłaszcza w miejscach trudno dostępnych podczas czyszczenia, skupisk drobnoustrojów w formie biofilmu. Wielogatunkowe biofilmy bakteryjne to złożone struktury charakteryzujące się opornością na wiele powszechnie stosowanych środków dezynfekcyjnych [15].

Celem niniejszego opracowania było przybliżenie mechanizmów tworzenia biofilmu bakteryjnego oraz jego występowania w różnych branżach przemysłu spożywczego, jak również omówienie możliwości jego skutecznej eliminacji ze środowiska produkcji żywności.

\section{Mechanizm powstawania biofilmu}

Formowanie matrycy biofilmu bakteryjnego jest procesem złożonym i wieloetapowym [26] - rys. 1. Niezależnie od rodzaju podłoża, na którym powstaje biofilm, pierwszym etapem jest adhezja pierwotna (odwracalna) uwarunkowana przyciąganiem elektrostatycznym, siłami van der Waalsa i wiązaniami kowalencyjnymi, podczas której tworzy się warstwa kontaktowa $[8,31]$. Na tym etapie u bakterii ważną rolę odgrywa obecność rzęsek (np. u E. coli) lub wici (np. u Pseudomonas aeruginosa) [26, 45]. Podczas kolejnego etapu (adhezja nieodwracalna) rozpoczyna się produkcja macierzy zewnątrzkomórkowej EPS (ang. Extracellular Polimeric Substances) [8] oraz tworzenie zasadniczej warstwy biofilmu nieodwracalnie związanej z podłożem [31]. Adhezja nieodwracalna związana jest z procesem namnażania komórek bakteryjnych oraz aktywowania procesu ich wewnętrznej komunikacji zwanego quorum sensing (QS), prowadząc do formowania dojrzałego biofilmu [32]. Powstały biofilm bakteryjny tworzy strukturę biologiczną zróżnicowaną pod względem budowy i rodzaju zasiedlających go drobnoustrojów [45]. Odłączenie komórek od powierzchni skolonizowanego materiału jest ostatnim etapem, który jest aktywowany w momencie osiągnięcia grubości krytycznej danej populacji w biofilmie regulowanej przez $Q S$ lub wzmożonym stresem środowiskowym, tj. brakiem substancji odżywczych czy obecnością związków o właściwościach przeciwdrobnoustojowych [1].

Najczęściej spotykaną strukturą biofilmu w przemyśle spożywczym jest forma kolumnowa oraz model grzyba $[3,26]$. Biofilm kolumnowy nazywany inaczej „modelem heterogennej mozaiki” tworzony jest najczęściej przez E. coli i P. aeruginosa. 


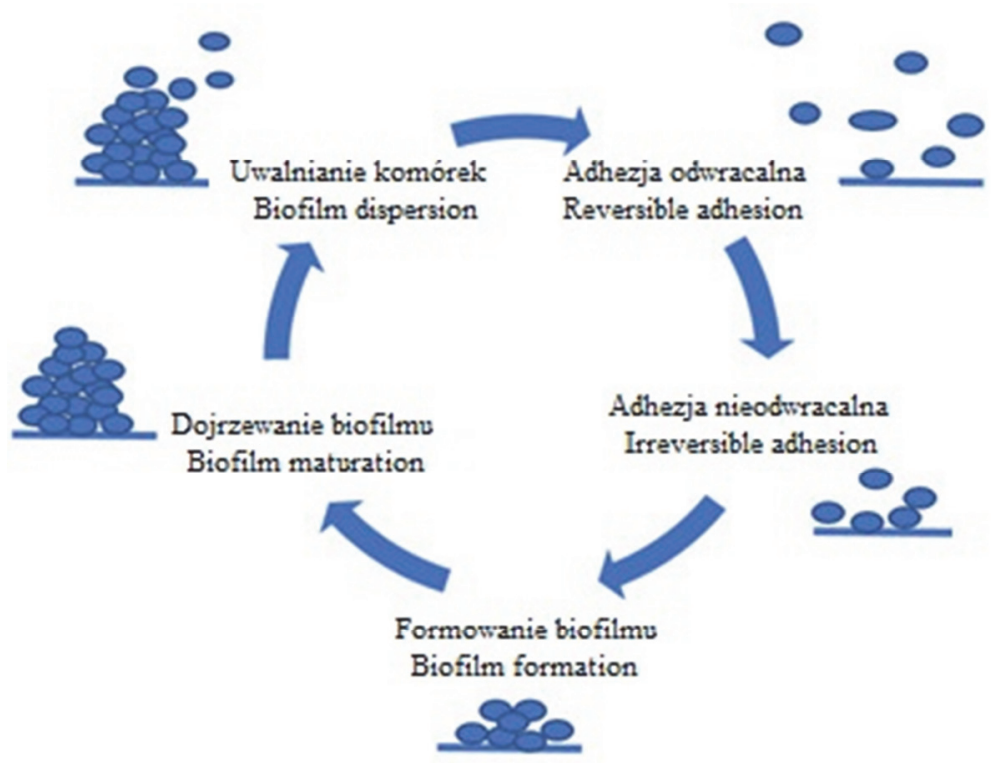

Rys. 1. Uproszczony schemat etapów rozwoju biofilmu

Fig. 1. Simplified chart of biofilm development stages

Źródło / Source: opracowanie własne / the authors' own study

Rola macierzy zewnątrzkomórkowej biofilmu (EPS)

Komórki bakteryjne w biofilmach otoczone są macierzami zewnątrzkomórkowymi, zwanymi egzopolisacharydami (EPS), których składniki pełnią ważną rolę w funkcjonowaniu biofilmu. Macierz biofilmu stanowi polimerowy śluz składający się z polisacharydów, białek, fosfolipidów, kwasów nukleinowych, substancji powierzchniowo czynnych oraz wody [7, 8]. Funkcją EPS jest unieruchomienie komórek bakteryjnych w biofilmie, co sprzyja wzajemnej komunikacji bakterii oraz wychwytywaniu substancji odżywczych będących źródłem energii [26]. W zależności od drobnoustrojów obecnych w biofilmie struktura chemiczna EPS jest zróżnicowana, a skład ilościowy i jakościowy substancji odżywczych wpływa na ilość wytwarzanego polimeru. Obecność kanałów transportowych w biofilmie powoduje, że komórki bakterii znajdujące się w warstwie powierzchniowej są metabolicznie aktywne, a ich rozwój wpływa na rozrost struktury biofilmu. Bakterie znajdujące się w głębszych warstwach biofilmu są w stanie anabiozy lub powolnego wzrostu. Dostępność tlenu w głębszych warstwach jest ograniczona, co prowadzi do aktywacji alternatywnych szlaków oddychania komórkowego. Różnorodność gatunkowa drobnoustrojów tworzących biofilm wpływa na jego integralność oraz wzajemną ochronę przed ekspozycją na czynniki środowiskowe, 
tj. neutralizację substancji chemicznych [7]. W tab. 1. przedstawiono wybrane składniki zewnątrzkomórkowej macierzy polimerycznej i funkcje, jakie pełnią.

Tabela 1. Podstawowe funkcje pełnione przez wybrane składniki zewnątrzkomórkowej macierzy polimerycznej

Table 1. Basic functions performed by selected components of the extracellular polymeric matrix

\begin{tabular}{||l|l||}
\hline \multicolumn{1}{|c|}{$\begin{array}{c}\text { Składniki EPS } \\
\text { Components of EPS }\end{array}$} & \multicolumn{1}{c|}{ Funkcja / Function } \\
\hline $\begin{array}{l}\text { Polisacharydy, DNA, } \\
\text { białka / Polysaccharides, } \\
\text { DNA, proteins }\end{array}$ & $\begin{array}{l}\text { Adhezja komórek bakteryjnych do powierzchni abiotycznych } \\
\text { i biotycznych; łączenie komórek bakteryjnych i wzajemne rozpoznawanie } \\
\text { Bacterial cells adhesion to abiotic and biotic surfaces; fusion of bacterial } \\
\text { cells and mutual recognition }\end{array}$ \\
\hline $\begin{array}{l}\text { Polisacharydy i białka } \\
\text { Polysaccharides and } \\
\text { proteins }\end{array}$ & $\begin{array}{l}\text { Bariera ochronna przed związkami o działaniu przeciwdrobnoustrojowym } \\
\text { Protective barrier against compounds with antimicrobial activity }\end{array}$ \\
\hline Białka / Proteins & $\begin{array}{l}\text { Aktywność enzymatyczna rozkładająca makrocząsteczki do prostego } \\
\text { substratu pokarmowego; aktywność enzymatyczna umożliwiająca } \\
\text { uwolnienie komórek z biofilmu / Enzymatic activity to break down macro- } \\
\text { molecules into simple food substrate; enzymatic activity which allows cell } \\
\text { releasing from biofilm }\end{array}$ \\
\hline DNA & $\begin{array}{l}\text { Wymiana materiału genetycznego pomiędzy komórkami w biofilmie } \\
\text { spowodowana horyzontalnym transferem genów / Genetic material } \\
\text { exchange between biofilms cells coused by horizontal gene transfer }\end{array}$ \\
\hline $\begin{array}{l}\text { Ramnolipidy } \\
\text { Rhamnolipids }\end{array}$ & $\begin{array}{l}\text { Wykluczenie niektórych gatunków ze struktury biofilmu; wpływ na } \\
\text { funkcjonalność kanałów transportowych / Exclusion of some species from } \\
\text { biofilm structure; impact on functionality of transport channels }\end{array}$ \\
\hline $\begin{array}{l}\text { Wszystkie polimery EPS } \\
\text { All EPS polymers }\end{array}$ & $\begin{array}{l}\text { Źródło energii pokarmowej ze związków węgla, potasu i azotu / Source of } \\
\text { food energy from carbon, potassium and nitrogen compounds }\end{array}$ \\
\hline
\end{tabular}

Źódło / Source: opracowanie własne na podstawie $[8,20,25]$ / the authors' own study based on $[8,20$, 25]

\section{Rola quorum sensing (QS) w funkcjonowaniu biofilmu bakteryjnego}

System QS (wyczuwania liczebności) jest procesem komunikacji międzykomórkowej umożliwiającym wydzielanie specyficznych cząsteczek sygnałowych w odpowiedzi na zmiany gęstości komórek bakteryjnych tworzących biofilm [32]. Wykrywanie kworum przez populację bakteryjną reguluje etapy tworzenia biofilmu poprzez aktywację ekspresji genów odpowiedzialnych za funkcjonowanie biofilmu. Aktywacja głównego genu bakteryjnego - pelA - powodującego wydzielanie macierzy zewnątrzkomórkowej [11] i białek tworzy organizm wielokomórkowy oporny na eradykację [53]. Oprócz formowania błony biologicznej $Q S$ aktywuje geny związane z syntezą bakteriocyn, przetrwalników oraz regulacją wirulencji i apoptozy. Zdolność komunikacji między bakteriami umożliwia podział funkcji biologicznych w biofilmie i adaptację do środowiska zewnętrznego. W wyczuwaniu kworum pośredniczą cząsteczki sygnałowe zwane autoinduktorami (AI) [32], wydzielane w zależności od wzrostu liczby 
bakterii tworzących biofilm [9], które są wiązane przez receptory białkowe komórek bakteryjnych [19]. System wzajemnej komunikacji związany z AI determinuje odmienna budowa ściany komórkowej bakterii, a komunikacja zachodzi na poziomie tego samego lub różnych gatunków [28]. Bakterie Gram-ujemne wydzielają cząsteczki sygnałowe, zwane AHL (laktony N-acylo-L-homoseryny), zbudowane z laktonu homoseryny, który w pozycji $\alpha$ jest acylowany kwasem thuszczowym [24, 32]. Cząsteczki sygnałowe bakterii Gram-ujemnych różnią się między sobą liczbą atomów węgla w łańcuchu, budową kwasu tłuszczowego oraz stopniem utlenienia. Niejednorodna budowa strukturalna biofilmu umożliwia bakteriom stworzenie własnego ,języka", niezbędnego do komunikacji w obrębie każdego gatunku [20]. Bakterie Gram-dodatnie wydzielają cząsteczki sygnałowe AIP, czyli oligopeptydy autoindukcyjne, dwuskładnikowe białka, które przekazują sygnał do komórki za pomocą mechanizmu fosforylacji i defosforylacji oraz regulują ekspresję genów powiązanych w komórce [53]. Dyfuzja AIP do cytoplazmy odbywa się za pomocą białka transportowego zależnego od ATP [47]. Powszechnie znanym systemem komunikacji bakterii Gram-ujemnych i Gram-dodatnich są autoinduktory typu drugiego (AL-2) umożliwiające komunikację międzygatunkową w biofilmach mieszanych [53]. AL-2 wydzielane są przez bakterie z rodzajów Bacillus, Campylobacter, Enterococcus, Klebsiella, Listeria, Salmonella, Staphylococcus, Streptococcus, Yersinia i Vibrio [53]. Dokładne poznanie mechanizmu $Q S$ w funkcjonowaniu biofilmu bakteryjnego umożliwi w przyszłości opracowanie nowoczesnych metod inhibicji tworzenia biofilmów w przemyśle rolno-spożywczym.

\section{Występowanie biofilmów bakteryjnych w przemyśle spożywczym}

Biofilmy bakteryjne występują powszechnie w wielu gałęziach przemysłu spożywczego. Stanowią one źródło zanieczyszczeń mikrobiologicznych żywności, powodują obniżenie jakości i trwałości produktów spożywczych.

\section{Biofilmy w przemyśle mięsnym}

W przemyśle mięsnym zanieczyszczenia spowodowane bakteriami patogennymi są poważnym problemem dla zdrowia publicznego i często prowadzą do wycofania produktów ze sprzedaży, co powoduje znaczne straty finansowe producentów [15]. Do zanieczyszczenia mięsa dochodzi głównie podczas uboju oraz dalszej jego obróbki. Linie produkcyjne są uznawane za główne źródło zanieczyszczeń krzyżowych w całym łańcuchu żywnościowym. Głównymi patogenami bakteryjnymi występującymi w przemyśle mięsnym są: Salmonella, L. monocytogenes, E. coli, Campylobacter jejuni oraz Staphylococcus aureus [48].

Pałeczki z rodzaju Salmonella są jednym z głównych patogenów przenoszonych przez mięso i produkty drobiowe, a konieczność wykrywania tych bakterii w żywności jest regulowana prawnie. W środowisku produkcyjnym Salmonella tworzy biofilm na 
różnych powierzchniach, a zdolność ta jest koordynowana przez złożony program ekspresji genów i aktywność odpowiednich białek w zależności od serowaru patogenu, powierzchni produkcyjnej oraz warunków środowiskowych [15]. W trakcie tworzenia biofilmu Salmonella wytwarza celulozę oraz wykorzystuje fimbrie (włosowate struktury, których główną funkcją jest ułatwianie adhezji bakterii do innych komórek) [1, 14]. Innym istotnym patogenem związanym z przemysłem mięsnym jest $L$. monocytogenes, czynnik etiologiczny listeriozy, choroby o stosunkowo wysokim wskaźniku śmiertelności (ok. $20 \%$ \%) [39]. Z uwagi na zdolność przylegania do powierzchni stałych oraz adaptację do warunków stresowych (niski poziom składników odżywczych, wahania $\mathrm{pH}$ i niska temperatura) biofilm utworzony przez tę bakterię może być obecny w zakładach przetwórstwa żywności przez wiele lat [1]. Bakterie L. monocytogenes mogą tworzyć biofilmy wielogatunkowe (mieszane) z innymi bakteriami występującymi w produktach mięsnych, tj. Pseudomonas oraz Carnobacterium, rodziną Enterobacteriaceae czy bakteriami kwasu mlekowego (LAB, ang. Lactic Acid Bacteria) [15, 48]. Enterokrwotoczne E. coli (EHEC, ang. enterohemorrhagic E. coli) wytwarzają toksynę Shiga (STEC, ang. Shiga-toxin producing E. coli). W warunkach naturalnych kolonizują przewód pokarmowy bydła, a do środowiska przedostają się wraz z odchodami swoich gospodarzy. Do zanieczyszczenia tymi bakteriami dochodzi głównie podczas skórowania zwierząt, gdy zostaje odsłonięta macierz zewnątrzkomórkowa mięśni szkieletowych. Podczas interakcji z powierzchnią biotyczną lub abiotyczną patogen ten angażuje różne mechanizmy molekularne aktywujące ekspresję odpowiednich genów [15]. Wśród EHEC najczęściej izolowana jest $E$. coli O157:H7, której w przytwierdzeniu do powierzchni mięsa i w późniejszym tworzeniu biofilmu pomagają inne, oporne na środki dezynfekujące mikroorganizmy, np. Acinetobacter calcoaceticus [48].

Głównym źródłem C. jejuni, podobnie jak w przypadku Salmonella, jest drób. W porównaniu z wcześniej omówionymi patogenami pałeczki $C$. jejuni są wrażliwe zarówno pod względem wymagań rozwojowych, jak i na czynniki środowiskowe. Tworzenie biofilmu jest kluczowym czynnikiem umożliwiającym przetrwanie tych bakterii w środowisku produkcji i przetwarzania żywności [4]. Patogenność S. aureus związana jest natomiast z wytwarzaniem szeregu termostabilnych enterotoksyn. Do zanieczyszczenia produktów mięsnych może dochodzić podczas uboju zwierząt, zanieczyszczenia krzyżowego w trakcie przygotowywania żywności oraz bezpośredniego kontaktu z zakażonymi osobami mającymi kontakt z żywnością, będącymi bezobjawowymi nosicielami enterotoksycznych $S$. aureus [15].

\section{Biofilmy w przemyśle mleczarskim}

Z uwagi na dużą zawartość składników odżywczych mleko jest środowiskiem sprzyjającym wzrostowi patogennych bakterii tworzących biofilmy. W zakładach mleczarskich biofilmy bakteryjne występują w zbiornikach, rurach, na powierzchniach 
roboczych, ścianach oraz na podłogach [30]. Najczęściej izolowanymi bakteriami z linii produkcyjnych są rodzaje Pseudomonas, Serratia oraz gatunki Staphylococcus sciuri i Stenotrophomonas maltophilia. Do powstawania biofilmów mieszanych często dochodzi na membranach do ultrafiltracji i odwróconej osmozy. Macierz biofilmu, która jest oporna na czyszczenie i dezynfekcję, stanowi potencjalne źródło zanieczyszczenia mleka oraz powoduje problemy techniczne (zatykanie porów membran filtrów, wzrost kosztów energii). Obecność w środowisku mleka bakterii LAB może mieć silny antagonistyczny wpływ zarówno na osadzanie patogenów na powierzchniach, jak również na ich proliferację. Z surowego mleka i niepasteryzowanych produktów mlecznych powszechnie izoluje się L. monocytogenes, która wraz z bakteriami z rodzajów Citrobacter i Lactococcus wchodzi w skład biofilmów występujących na powierzchniach urządzeń przeznaczonych do dojenia [15]. Bakterie z gatunku S. aureus stanowią główny czynnik etiologiczny odpowiedzialny za ostre i przewlekłe zapalenie wymienia u krów (mastitis). W patogenezie zapalenia gruczołu mlekowego głównym czynnikiem zjadliwości jest zdolność do tworzenia biofilmów opornych na środki przeciwdrobnoustrojowe. Tworzenie przez $S$. aureus biofilmu jest związane z produkcją polisacharydowej adhezyny międzykomórkowej i kilku białek [41]. Zagrożenie w przemyśle mleczarskim stanowi rodzaj Bacillus, jak również inne bakterie tworzące przetrwalniki, z uwagi na zdolność do przetrwania procesu pasteryzacji i tworzenia biofilmów w rurociągach poboru mleka. Biofilm chroni osadzone w nim przetrwalniki przed inaktywacją [21]. Ponadto kwas masłowy oraz wolne kwasy tłuszczowe uwalniane podczas lipolizy thuszczu mlecznego powodują tworzenie struktur związanych z biofilmem, które dodatkowo chronią bakterie przed niekorzystnymi warunkami środowiska [34]. Bakterie z rodzaju Cronobacter sporadycznie zanieczyszczają mleko w proszku (a zatem również produkty dla niemowląt), przyczyniając się do wywoływania zapalenia opon mózgowo-rdzeniowych. Z uwagi na możliwość tworzenia biofilmu są oporne na powszechnie stosowane środki odkażające [15].

Biofilmy w produkcji ryb i owoców morza

Czynniki bakteryjne związane ze spożywaniem owoców morza są odpowiedzialne za większość zakażeń wymagających hospitalizacji. Warstwa śluzu na powierzchni ryb stanowi pierwszą barierę dla zagrożeń zewnętrznych, zawiera liczne związki przeciwbakteryjne (m.in. immunoglobuliny, aglutyniny, lektyny, lizyny i lizozym). Owoce morza są podatne na zanieczyszczenia powierzchniowe lub tkankowe, zwłaszcza w przypadku hodowli w obszarach zanieczyszczonych ściekami komunalnymi. Dodatkowe ryzyko stanowi spożywanie surowych lub niedogotowanych owoców morza. Najczęściej izolowanymi bakteriami są rodzaje Pseudomonas, Listeria, Stenotrophomonas, Brochothrix, Serratia, Acinetobacter, Rhodococcus i Chryseobacterium, które mogą tworzyć stabilne biofilmy [15]. Powszechnie izolowanymi patogenami bakteryj- 
nymi owoców morza zdolnymi do tworzenia biofilmów są: Vibrio spp., Aeromonas hydrophila, Salmonella spp. oraz L. monocytogenes. Zdolność do szybkiej kolonizacji powierzchni owoców morza przez te patogeny (zwłaszcza w biofilmach mieszanych) zmniejsza skuteczność stosowanych metod dezynfekcji. Biofilmy formowane przez patogenne dla człowieka szczepy Vibrio stanowią zanieczyszczenie akwakultury morskiej [12], ponieważ mogą koncentrować się w skorupiakach filtrujących (np. małże podczas filtracji wody gromadzą mikroflorę patogenną) [15]. Zdolność do tworzenia biofilmu wynika $\mathrm{z}$ aktywności genów odpowiedzialnych za syntezę pilusów, wici i egzopolisacharydów oraz mechanizmów regulacyjnych (dwuskładnikowych regulatorów transdukcji sygnału oraz sygnalizacji $Q S$ ). Bakterie z rodzaju Aeromonas stanowią naturalną mikroflorę jelit wielu ryb. Wytwarzanie biofilmu przez A. hydrophila jest ściśle skorelowane $\mathrm{z}$ ich wirulencją. Bakterie te łatwo tworzą cienki biofilm o złożonej strukturze [17]. Pałeczki A. hydrophila mają system $Q S$ zależny od $\mathrm{N}$-acylohomoseryny (AHL), bazujący na locus ahyRI. Wykazano, że rozwój biofilmu przez te bakterie jest regulowany przez $Q S$. Istotny problem w produkcji rybnej stanowią również bakterie L. monocytogenes [15].

\section{Biofilmy w produktach pochodzenia roślinnego o minimalnym stopniu przetworzenia}

Coraz częstszym problemem są zatrucia spowodowane spożyciem produktów o minimalnym stopniu przetworzenia pochodzenia roślinnego zanieczyszczonych mikroflorą patogenną. W celu zmniejszenia liczby drobnoustrojów na powierzchni owoców i warzyw producenci stosują mycie $\mathrm{z}$ dodatkiem środków odkażających. $\mathrm{Z}$ uwagi na silne przywiązanie przylegających patogenów do powierzchni produktów (czemu sprzyjają nierówności powierzchni, tj. szorstkość, szczeliny i wgłębienia), mycie w niewielkim stopniu redukuje ich liczbę. Najczęściej izolowanymi z żywności minimalnie przetworzonej pochodzenia roślinnego bakteryjnymi patogenami tworzącymi biofilmy są: $S$. enterica, L. monocytogenes i E. coli. Ponadto z biofilmów na powierzchni kapusty i sałaty wyizolowano Bacillus cereus i A. hydrophila [15]. Rodzaj Salmonella, pomimo narażenia na stres środowiskowy, skutecznie utrzymuje się na powierzchni rośliny, co związane jest z produkcją celulozy i innych polisacharydów, zdolnością penetracji tkanki roślinnej i możliwością wbudowywania do już istniejących biofilmów wielogatunkowych [23]. W mechanizmie początkowego przyczepiania i rozwoju biofilmu ważną rolę odgrywają wici oraz powierzchniowe struktury komórkowe tych bakterii, m.in. fimbrie [1].

\section{Biofilmy w przemyśle sokowniczym}

Głównym problemem przemysłu sokowniczego i koncentratów soków owocowych są zepsucia powodowane występowaniem acidotermofilnych bakterii z rodzaju Alicyclobacillus, zwłaszcza gatunku A. acidoterrestris. Zarówno komórki tych bakterii, 
jak i ich przetrwalniki tworzą na powierzchni urządzeń przetwórczych trudny do usunięcia biofilm [22]. Materiały spożywcze ułatwiają przyleganie bakterii do powierzchni. Wykazano, że wodne powłoki spożywcze mogą zmniejszać adhezję komórek bakteryjnych, przez co utrudniają tworzenie macierzy biofilmu w środowisku produkcyjnym.

\section{Metody usuwania biofilmów spożywczych}

Różnorodność mikroorganizmów obecnych w biofilmach oraz stopień ich rozwoju wpływają na wybór odpowiedniej metody eradykacji biofilmu. Uważa się, że najlepszą strategią usuwania biofilmu jest zapobieganie jego rozwojowi. Odpowiednio zaprojektowany sprzęt produkcyjny w połączeniu ze środkami higieny prowadzi do usuwania niepożądanych resztek żywności, w tym drobnoustrojów [29]. Stosowane antybakteryjne dodatki do żywności, tj. środki powierzchniowo czynne, olejki eteryczne czy barwniki stanowią skuteczne bariery zapobiegające formowaniu błony biologicznej w przemyśle spożywczym [53]. Prowadzone są badania dotyczące inhibitorów roślinnych wykrywających $Q S$. Wykazano, że składniki roślin wykorzystywanych w tradycyjnej medycynie chińskiej hamują tworzenie biofilmu [6]. Przykładem jest emodyna, naturalny składnik korzeni wielu roślin, który istotnie hamuje bakteryjny system wytwarzający kworum, np. u bakterii z gatunku $P$. aeruginosa [37]. Furanony izolowane z morskiego glona Delisea pulchra są zdolne do usuwania autoinduktorów $\mathrm{z}$ komórek E. coli [50]. Zwalczanie patogenów w ich chronionym środowisku polimerowym jest powszechnym problemem, z którym zmaga się przemysł spożywczy [49].

W zwalczaniu biofilmów bakteryjnych stosowane są metody fizyczne, chemiczne oraz biologiczne [52].

\section{Metody fizyczne}

Klasycznym sposobem eliminacji biofilmu jest zastosowanie metod fizycznych, tj. mechaniczne niszczenie macierzy biofilmu poprzez skrobanie i szorowanie. Techniki te cechuje niska precyzja ze względu na różnorodną budowę sprzętu produkcyjnego. Oprócz działania mechanicznego można zastosować wysoką temperaturę (powyżej $95^{\circ} \mathrm{C}$ ) lub kilkakrotne zamrażanie [27]. Skuteczną metodą usuwania biofilmu jest zastosowanie zimnej plazmy [35, 52]. Jest to mieszanina naładowanych cząsteczek, jonów, atomów i wolnych rodników w połączeniu z promieniowaniem UV. Uważa się, że mieszanina tych substancji czynnych zakłóca metaboliczne szlaki i integralność błony komórkowej bakterii [54].

\section{Metody chemiczne}

Substancje chemiczne stosowane w przemyśle spożywczym powinny charakteryzować się nie tylko skutecznością w zwalczaniu drobnoustrojów, ale także szybkością 
i łatwością spłukiwania $\mathrm{z}$ urządzeń produkcyjnych. $\mathrm{Z}$ uwagi na to, że powstawanie biofilmu jest procesem wieloetapowym, na rynku dostępne są środki chemiczne o różniej aktywności działania na drobnoustroje [10]. Preparaty dezynfekujące zawierające związki chloru i kwas nadoctowy są często stosowane w branży owocowo-warzywnej [1]. Wykazano, że gazowy dwutlenek chloru jest skuteczny w niszczeniu endosporów bakterii z gatunku $B$. cereus obecnych na urządzeniach przemysłowych [33]. Stwierdzono, że podchloryny stanowią najskuteczniejsze związki chloru stosowane w odkażaniu powierzchni roboczych. Ich wadą jest mała rozpuszczalność w wodzie i możliwość korozji powierzchni metalowych przy wysokiej temperaturze [1]. W przemyśle mięsnym i jajecznym do dezynfekcji powierzchni stosuje się kwas nadoctowy ze względu na brak toksycznych pozostałości. Innym rozwiązaniem jest używanie nadtlenku wodoru w stężeniu do $5 \%$, który generuje wolne rodniki w trakcie kontaktu z zewnątrzkomórkowymi substancjami polimerowymi, niszcząc strukturę biofilmu bez powstawania toksycznych produktów ubocznych [43]. Gazem o silnym działaniu utleniającym jest ozon, który niszczy wiele mikroorganizmów tworzących biofilm. Ozon wykorzystuje się w przemyśle mleczarskim do dezynfekcji stali nierdzewnej używanej przy produkcji serów pleśniowych $[43,46]$. Powszechnie stosowanymi środkami dezynfekcyjnymi w różnych gałęziach sektora spożywczego są czwartorzędowe związki amoniowe (QAC) powodujące lizę komórek bakteryjnych tworzących strukturę biofilmu [18].

Innym sposobem niszczenia biofilmów spożywczych jest wykorzystywanie właściwości kwasów organicznych, np. cytrynowego, jabłkowego oraz galusowego jako alternatywnych środków kontroli tworzenia biofilmu w przemyśle mleczarskim. Źródłem tych kwasów są rośliny, które pod względem oczekiwań konsumentów nie budzą tylu zastrzeżeń, co związki chloru powszechnie stosowane do niszczenia biofilmu [42]. Akbas i Kokumer [2] potwierdzili, że użycie 2- i 10-procentowego kwasu cytrynowego przez 20 min wyeliminowało bakterie $S$. aureus z powierzchni ze stali nierdzewnej. Wymienieni autorzy zastosowali w doświadczeniu także 0,3-procentowy kwas nadoctowy, który charakteryzował się mniejszą skutecznością usuwania biofilmu w porównaniu z zastosowanymi kwasami organicznymi.

Kolejną grupą związków pochodzenia roślinnego o właściwościach niszczących biofilmy są olejki eteryczne [13]. Substancje te działają antybakteryjnie i przeciwgrzybiczo, zwłaszcza w warunkach in vitro [40, 44]. Raffaella i wsp. [38] zastosowali mikroemulsję olejku z Cinnamomum cassia (bogatego w aldehyd cynamonowy). W błonie utworzonej przez 24-godzinny biofilm $S$. aureus uzyskali zredukowanie liczby bakterii o 4 rzędy logarytmiczne (99,99 \%). Innym przykładem jest cytral, główny składnik olejku z trawy cytrynowej, który utrudnia tworzenie biofilmu bakteryjnego. Shi i wsp. [42] przy użyciu tego związku zmniejszyli poziom czynnika wirulencji i biosyntezę wici u Cronobacter sakazakii. Różnorodność chemiczna olejków pozy- 
skiwanych z roślin pozwala naukowcom na opracowanie preparatów przeciw biofilmom lub wykorzystanie poszczególnych składników, dodając je bezpośrednio do produktów spożywczych. Olejki eteryczne pozyskiwane z lebiodki pospolitej (oregano) wykazują właściwości antyadhezyjne, które są kluczowe w powstawaniu biofilmu. Wykazano, że monoterpen i karwakrol z olejku eterycznego oregano można zastosować bezpośrednio do produkcji soków, octu i mięsa mielonego w celu zahamowania wzrostu bakterii z gatunków $S$. enterica czy Clostridium perfringens [13].

\section{Metody biologiczne}

Do metod biologicznej eliminacji biofilmów bakteryjnych należy stosowanie wirusów bakteryjnych (bakteriofagów, fagów) lub bezpośrednio oczyszczonych enzymów fagowych [36]. Zastosowanie bakteriofagów w przemyśle spożywczym jest stosunkowo nową koncepcją utrwalania żywności [39]. Na rynku dostępne są preparaty bazujące na fagach litycznych ukierunkowanych na określone rodzaje lub szczepy patogenów żywności, w tym Salmonella, L. monocytogenes, E. coli O157:H7 czy Shigella. Wiele z tych preparatów ma status GRAS, rekomendację FDA (ang. Food and Drag Administration) oraz certyfikat koszerności [39,51]. W Polsce preparaty te nie są dopuszczone do stosowania w przemyśle spożywczym. Natomiast komercyjne środki fagowe są stosowane m.in. w Australii, Brazylii, Holandii, Izraelu, Kanadzie, Nowej Zelandii, Szwajcarii czy USA [39]. Początkowo zakładano, że biofilmy są barierą dla bakteriofagów z uwagi na nieprzepuszczalność macierzy biofilmu. Okazuje się, że wiele bakteriofagów może funkcjonować w biofilmie i aktywnie się w nim namnażać. Bakteriofagi wykazują inny mechanizm niszczenia biofilmu niż antybiotyki czy biocydy. Fagi ewoluowały z biofilmami bakteryjnymi. Wyróżnia się co najmniej cztery mechanizmy różnicujące ich działanie [16] - rys. 2.

Inną koncepcją biologicznego niszczenia biofilmów jest wykorzystanie oczyszczonych enzymów fagowych. Genomy fagów zawierają wiele genów kodujących enzymy służące do rozkładu macierzy biofilmu. Zazwyczaj celują one w ścianę komórkową bakterii podczas uwalniania $\mathrm{z}$ komórki gospodarza oraz mają możliwość degradacji egzopolisacharydów tworzących biofilm [16]. Depolimerazy fagowe charakteryzują się różną aktywnością. Zaliczane są do enzymów szczepowo specyficznych i stanowią istotny problem w przypadku eradykcji biofilmu mieszanego. Innymi enzymami fagowymi są endolizyny, które uczestniczą w cyklu litycznym. Specyficzność tych enzymów, podobnie jak fagów, które je produkują, jest zwykle duża [5]. W połączeniu z białkiem fagoliną enzymy te powodują lizę komórki bakteryjnej od wewnątrz $[5,36]$. Kolejną grupą enzymów fagowych są DNazy, które uwalniane do środowiska powodują degradację bakteryjnego DNA [16]. Znaczną grupę stanowią białka zaliczane do enzymów ogona fagowego, które wykazują jednak ograniczone działanie, ponieważ są często maskowane do czasu rekonfiguracji ogona bakteriofaga podczas in- 
fekcji [5]. Główną zaletą stosowania enzymów fagowych jest brak ryzyka transferu genów pomiędzy populacjami bakteryjnymi. Wadę z kolei stanowi to, że same enzymy musiałyby być dodawane cyklicznie do biofilmu, podczas gdy fagi samoczynnie zwiększają swoją dawkę podczas infekcji komórek bakteryjnego gospodarza [51].

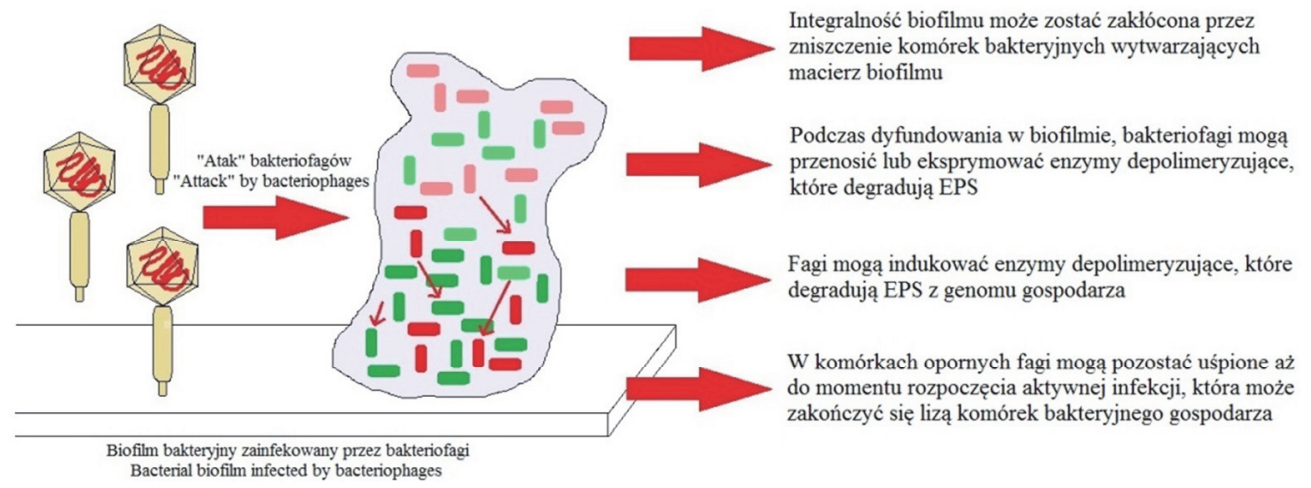

Objaśnienia / Explanatory notes:

Integralność biofilmu może zostać zakłócona przez zniszczenie komórek bakteryjnych wytwarzających macierz biofilmu / Integrity of biofilm can be disrupted by destruction of bacterial cells that produce the biofilm matrix; Podczas dyfundowania w biofilmie, bakteriofagi mogą przenosić lub eksprymować enzymy depolimeryzujące, które degradują EPS / When diffusing through biofilm, bacteriophages can carry or express depolymerising enzymes that degrade EPS; Fagi mogą indukować enzymy depolimeryzujące, które degradują EPS z genomu gospodarza / Phages can induce depolymerising enzymes that degrade EPS from host genome; W komórkach opornych fagi mogą pozostać uśpione aż do momentu rozpoczęcia aktywnej infekcji, która może zakończyć się lizą komórek bakteryjnego gospodarza / In resistant cells phages can remain dormant until active infection begins, that can result in lysis of bacterial cells of host.

Rys. 2. Mechanizmy działania fagów na biofilm bakteryjny

Fig. 2. Modes of action of phages in bacterial biofilm

Źródło / Source: opracowanie własne na podstawie [16] / the authors' own study based on [16]

\section{Metody kombinowane}

Wyższą skuteczność eliminacji biofilmów można osiągnąć dzięki połączeniu kilku technik dezynfekcji. Wykazano, że kombinacja związków chemicznych z promieniowaniem UV efektywnie usuwa biofilm $P$. aeruginosa [53]. Inną metodą jest połączenie enzymów proteolitycznych $\mathrm{z}$ falami ultradźwiękowymi. Przykładowo, zastosowanie takiej techniki przez 10 min eliminuje $96 \%$ biofilmu E. coli obecnego na powierzchni stalowej w zakładzie mleczarskim [13]. 


\section{Podsumowanie}

Drobnoustroje tworzące biofilmy stanowią poważny problem w sektorze produkcji żywności, powodując straty finansowe w danym sektorze spożywczym oraz zagrożenie zdrowia konsumenta. Obecność biofilmów bakteryjnych została potwierdzona m.in. w przemyśle mięsnym, mleczarskim, sokowniczym, ryb i owoców morza oraz żywności świeżej gotowej do spożycia. Powstawanie biofilmu jest procesem dynamicznym składającym się z kilku etapów, na które wpływają odpowiednie czynniki środowiskowe. Dostępność składników odżywczych na powierzchni produktów spożywczych lub pochodzących z powierzchni linii produkcyjnej jest głównym czynnikiem stymulującym namnażanie komórek bakteryjnych, a następnie formowanie wielogatunkowych biofilmów bakteryjnych. Drobnoustroje tworzące biofilm otoczone są zewnątrzkomórkową substancją polimerową (EPS), która chroni komórki bakteryjne przed środkami dezynfekcyjnymi oraz niekorzystnymi zmianami środowiska. Ponadto bakterie tworzące biofilm wykształciły zdolność wzajemnej komunikacji $(Q S)$, która steruje procesem rozwoju biofilmu i odgrywa ważną rolę w ochronie komórek. Wysoka oporność EPS na środki dezynfekujące stwarza trudności w wyborze odpowiedniej metody usuwania biofilmu. W celu eliminacji biofilmów bakteryjnych w przemyśle spożywczym stosuje się przede wszystkim metody fizyczne i chemiczne. Stały problem występowania biofilmów w zakładach przetwórczych zwraca uwagę na konieczność opracowywania nowych, alternatywnych metod jego eradykacji. Biologiczna metoda zwalczania biofilmów z zastosowaniem wirusów bakteryjnych oraz ich oczyszczonych enzymów litycznych lub zastosowanie metod kombinowanych może skutkować oczekiwanymi rezultatami. Opracowanie skutecznej metody eliminacji biofilmów ze środowiska produkcyjnego pozwoli na utrzymanie wysokiego poziomu higieny w zakładach przemysłu spożywczego.

Publikacja finansowana $w$ ramach działalności statutowej IBPRS-PIB nr 136-01 pt. „Molekularna i funkcjonalna analiza regulacji ekspresji genów i modułów genetycznych bioracych udziat w quorum sensing jako modutowej odpowiedzi sygnatowej bakterii” oraz nr 144-01 pt. „, Wykorzystanie bakteriofagów wobec Salmonella sp. jako innowacyjnej metody zapewnienia bezpieczeństwa mikrobiologicznego żywności”.

\section{Literatura}

[1] Akbas M.Y.: Bacterial biofilms and their new control strategies in food industry. In: The Battle Against Microbial Pathogens: Basic Science, Technological Advances and Educational Programs. Ed. A. Méndez-Vilas. Formatex Research Center, Badajoz 2015, pp. 383-394.

[2] Akbas M.Y., Kokumer T.: The prevention and removal of biofilm formation of Staphylococcus aureus strains isolated from raw milk samples by citric acid treatments. Int. J. Food Sci. Tech., 2015, 50 (7), 1666-1672. 
[3] Baranowska K., Rodziewicz A.: Molekularne interakcje w biofilmach bakteryjnych. Kosmos. Problemy Nauk Biologicznych, 2008, 57 (1-2), 29-38.

[4] Bronowski C., James C.E., Winstanley C.: Role of environmental survival in transmission of Campylobacter jejuni. FEMS Microbiol. Lett., 2014, 356 (1), 8-19.

[5] Chan B.K., Abedon S.T.: Bacteriophage and their enzymes in biofilm control. Curr. Pharm. Des., 2015, 21, 85-99.

[6] Chen Y., Liu T., Wang K., Hou C., Cai S., Huan Y., Du Z., Huang H., Kong J., Che Y.: Baicalein inhibits Staphylococcus aureus biofilm formation and the quorum sensing system in vitro. Plos One, 2016, 11 (4), \#0153468.

[7] Cłapa T., Selwet M., Narożna D.: Życie w społeczności - warunki powstawania biofilmu. Kosmos. Problemy Nauk Biologicznych, 2016, 65 (3), 463-468.

[8] Czaczyk K., Myszka K.: Biosynthesis of extracellular polymeric substances (EPS) and its role in microbial biofilm formation. Polish J. Environ. Stud., 2007, 16 (6), 799-806.

[9] Czyżewska-Dors E., Dors A., Pomorska-Mól M.: Właściwości biofilmu bakteryjnego warunkujące oporność na antybiotyki oraz metody jego zwalczania. Życie Weterynaryjne, 2018, 93 (11), 765771.

[10] Daniluk K.J.: Eliminacja biofilmów Listeria monocytogenes ze środowiska produkcji żywności. W: Listeria w przemyśle spożywczym. [on line]. Foodfakty. Dostęp w Internecie [20.04.2021]: https://foodfakty.pl/listeria-w-przemysle-spozywczym

[11] Frederick M.R., Kuttler C., Hense B.A., Eberl H.J.: A mathematical model of quorum sensing regulated EPS production in biofilm communities. Theor. Biol. Med. Model, 2011, 8, \#8.

[12] Froelich B.A., Noble R.T.: Vibrio bacteria in raw oysters: Managing risks to human health. Phil. Trans. R. Soc. B, 2016, 371 (1689), \#20150209.

[13] Galié S., García-Gutiérrez C., Miguélez E.M., Villar C.J., Lombó F.: Biofilms in the food industry: Health aspects and control methods. Front. Microbiol., 2018, 9, \#898.

[14] Giaouris E., Heir E., Hébraud M., Chorianopoulos N., Langsrud S., Møretrø T., Habimana O., Desvaux M., Renier S., Nychas G.-J.: Attachment and biofilm formation by foodborne bacteria in meat processing environments: Causes, implications, role of bacterial interactions and control by alternative novel methods. Meat Sci., 2014, 97 (3), 298-309.

[15] Giaouris E.E., Simões M.V.: Pathogenic biofilm formation in the food industry and alternative control strategies. In.: Foodborne Diseases. Eds. A.M. Holban, A.M. Grumezescu. Academic Press, London 2018, pp. 309-377.

[16] Harper D.R., Parracho H.M.R.T., Walker J., Sharp R., Hughes G., Werthén M., Lehman S., Morales S.: Bacteriophages and biofilms. Antibiotics, 2014, 3 (3), 270-284.

[17] Jahid I.K., Lee N.Y., Kim A., Ha S.D.: Influence of glucose concentrations on biofilm formation, motility, exoprotease production, and quorum sensing in Aeromonas hydrophila. J. Food Prot., 2013, 76 (2), 239-247.

[18] Jennings M.C., Minbiole K.P.C., Wuest W.M.: Quaternary ammonium compounds: An antimicrobial mainstay and platform for innovation to address bacterial resistance. ACS Infect. Dis., 2015, 1 (7), 288-303.

[19] Kishen A., Haapasalo M.: Biofilm models and methods of biofilm assessment. Endodontic Topics, 2010, 22 (1), 58-78.

[20] Kołwzan B.: Analiza zjawiska biofilmu - warunki jego powstawania i funkcjonowania. Ochrona Środowiska, 2011, 33 (4), 3-14.

[21] Kumari S., Sarkar P.K.: Bacillus cereus hazard and control in industrial dairy processing environment. Food Control, 2016, 69, 20-29.

[22] Kunicka-Styczyńska A.: Biofilmy bakteryjne w produkcji żywności. W: Bezpieczeństwo zdrowotne żywności. Aspekty mikrobiologiczne, chemiczne i ocena towaroznawcza. Red. J. Stadnik i I. Jackowska. Wyd. Nauk. PTTŻ, Kraków 2015, ss. 109-120.

[23] Lapidot A., Yaron S.: Transfer of Salmonella enterica serovar Typhimurium from contaminated irrigation water to parsley is dependent on curli and cellulose, the biofilm matrix components. J. Food Prot., 2009, 72 (3), 618-623. 
[24] Lipa P., Kozieł M., Janczarek M.: Zjawisko Quorum Sensing bakterii Gram-ujemnych: Cząsteczki sygnałowe i inhibitory oraz ich potencjalne zastosowanie terapeutyczne. Postępy Biochem., 2017, 63 (4), 242-260.

[25] Ławniczak Ł., Czaczyk K., Owsianiak M., Chrzanowski Ł.: Rola ramnolipidów w środowisku naturalnym. Post. Microbiol., 2011, 50 (1), 17-30.

[26] Łyszcz M.: Biofilm - złożona i wielokomórkowa struktura bakterii. W: Badania i Rozwój Młodych Naukowców w Polsce - Mikrobiologia i ekologia. Młodzi Naukowcy, Poznań 2020, ss. 54-60.

[27] Maciejewska M., Bauer M., Dawgul M.: Nowoczesne metody zwalczania biofilmu bakteryjnego. Post. Mikrobiol., 2016, 55 (1), 3-11.

[28] Matejczyk M., Suchowierska M.: Charakterystyka zjawiska Quorum Sensing i jego znaczenie w aspekcie formowania i funkcjonowania biofilmu w inżynierii środowiska, budownictwie, medycynie oraz gospodarstwie domowym. Budownictwo i Inżynieria Środowiska, 2011, 2 (1), 71-75.

[29] Merino L., Procura F., Trejo F.M., Bueno D.J., Golowczyc M.A.: Biofilm formation by Salmonella sp. in the poultry industry: Detection, control and eradication strategies. Food Res. Int., 2017, 119, 530-540.

[30] Mogha K.V., Shah N.P., Prajapati J.B., Chaudhari A.R.: Biofilm - A threat to dairy industry. Indian J. Dairy Sci., 2014, 67 (6), 459-466.

[31] Myszka K., Czaczyk K.: Characterization of adhesive exopolysaccharide (EPS) produced by Pseudomonas aeruginosa under starvation conditions. Curr. Microbiol., 2009, 58, 541-546.

[32] Myszka K., Czaczyk K.: Mechanizm Quorum Sensing jako czynnik regulujący wirulencję bakterii Gram-ujemnych. Postępy Hig. Med. Dośw., 2010, 64, 582-589.

[33] Nam H., Seo H.-S., Bang J., Kim H., Beuchat L.R., Ryu J.-H.: Efficacy of gaseous chlorine dioxide in inactivating Bacillus cereus spores attached to and in a biofilm on stainless steel. Int. J. Food Microbiol., 2014, 188, 122-127.

[34] Pasvolsky R., Zakin V., Ostrova I., Shemesh M.: Butyric acid released during milk lipolysis triggers biofilm formation of Bacillus species. Int. J. Food Microbiol., 2014, 181, 19-27.

[35] Patange A., Boehm D., Zuizina D., Cullen P.J., Gilmore B., Bourke P.: High voltage atmospheric cold air plasma control of bacterial biofilms on fresh produce. Int. J. Food Microbiol., 2019, 293, 137-145

[36] Połaska M., Sokołowska B.: Bacteriophages - a new hope or huge problem in the food industry. AIMS Microbiol., 2019, 5 (4), 324-346.

[37] Rabin N., Zheng Y., Opoku-Temeng C., Du Y., Bonsu E., Sintim H.O.: Agents that inhibit bacterial biofilm formation. Future Med. Chem., 2015, 7 (5), 647-671.

[38] Raffaella C., Casettari L., Fagioli L., Cespi M., Bonacucina G., Baffone W.: Activity of essential oilbased microemulsions against Staphylococcus aureus biofilms developed on stainless steel surface in different culture media and growth conditions. Int. J. Food Microbiol., 2017, 241, 132-140.

[39] Roszko M.Ł., Sokołowska B., Juszczuk-Kubiak E., Świder O., Wójcicki M.: Bakteriofagi jako czynniki biokontroli Listeria monocytogenes w przemyśle spożywczym. W: Listeria w przemyśle spożywczym. [on line]. Foodfakty. Dostęp w Internecie [20.04.2021]: https://foodfakty.pl/listeria-wprzemysle-spozywczym

[40] Sadowska A., Skarżyńska E., Rakowska R., Batogowska J., Waszkiewicz-Robak B.: Substancje bioaktywne w surowcach pochodzenia roślinnego i roślinach zielarskich. Post. Tech. Przetw. Spoż., 2014, 2, 131-135.

[41] Salimena A.P.S., Lange C.C., Camussone C., Signorini M., Calvinho L.F., Brito M.A.V.P., Borges C.A.V., Guimarães A.S., Ribeiro J.B., Mendonça L.C., Piccoli R.H.: Genotypic and phenotypic detection of capsular polysaccharide and biofilm formation in Staphylococcus aureus isolated from bovine milk collected from Brazilian dairy farms. Vet. Res. Commun., 2016, 40, 97-106.

[42] Shi C., Sun Y., Liu Z., Guo D., Sun H., Sun Z., Chen S., Zhang W., Wen Q., Peng X., Xia X.: Inhibition of Cronobacter sakazakii virulence factors by citral. Sci. Rep., 2017, 7, \#43243.

[43] Srey S., Jahid I.K., Ha S.-D.: Biofilm formation in food industries: A food safety concern. Food Control, 2013, 31 (2), 572-585.

[44] Śledź M., Witrowa-Rajchert D.: Składniki biologicznie czynne w suszonych ziołach - czy ciągle aktywne? Kosmos. Problemy Nauk Biologicznych, 2012, 61 (2), 319-329. 
[45] Tomczyk B., Kaźmierczuk M., Kalinowski R., Paczkowski S., Rybak J.: Biofilm: Źródło zagrożeń mikrobiologicznych w przemyśle. Przemysł Chemiczny, 2016, 95 (3), 581-586.

[46] Varga L., Szigeti J.: Use of ozone in the dairy industry: A review. Int. J. Dairy Technol., 2016, 69 (2), 157-168

[47] Wang M., Zhu P., Jiang J., Zhu H., Tan S.: Signaling molecules of quorum sensing in bacteria. Rev. Biotechnol. Biochem., 2020, 1 (1),\#002.

[48] Wang R.: Biofilms and meat safety: A mini-review. J. Food Protect., 2019, 82 (1), 120-127.

[49] Wolfmeier H., Pletzer D., Mansour S.C., Hancock R.E.W.: New perspectives in biofilm eradication. ACS Infect. Dis., 2018, 4 (2), 93-106.

[50] Wolska K.I., Grudniak A.M., Markowska K.: Związki interferujące z bakteryjnymi systemami wyczuwania liczebności i ich potencjalna funkcja terapeutyczna. Post. Mikrobiol., 2016, 55 (3), 300308.

[51] Wójcicki M., Błażejak S., Gientka I., Brzezicka K.: The concept of using bacteriophages to improve the microbiological quality of minimally-processed foods. Acta Sci. Pol. Technol. Aliment., 2019, 18 (4), 373-383.

[52] Zabielska J., Tyfa A., Kunicka-Styczyńska A.: Methods for eradication of the biofilms formed by opportunistic pathogens using novel techniques - A review. Acta Universitatis Lodziensis. Folia Biologica et Oecologica, 2016, 12, 26-37.

[53] Zhao X., Zhao F., Wang J., Zhong N.: Biofilm formation and control strategies of foodborne pathogens: Food safety perspectives. RSC Advances, 2017, 7, 36670-36683.

[54] Zhu Y., Li C., Cui H., Lin L.: Feasibility of cold plasma for the control of biofilms in food industry. Trends Food Sci. Tech., 2020, 99, 142-151.

\title{
BACTERIAL BIOFILM AND POSSIBILITIES OF ELIMINATING IT IN THE FOOD INDUSTRY
}

\author{
S u m m a ry
}

Bacterial biofilms occurring in the food industry are complex, multi-species consortia of both the saprophytic and the pathogenic bacteria. They are often localised on surfaces that are difficult to access for both the closed-circuit cleaning agents and the mechanical cleaning. In the food industry bacterial biofilms are a source of microbiological contamination of food, causing the quality and durability of food products to decrease. In addition, food biofilms can be a source of pathogenic bacteria, such as Salmonella spp., Campylobacter spp. or Listeria monocytogenes, and of opportunistic bacteria (e.g. Escherichia coli) that cause gastrointestinal diseases, which can be long-lasting and difficult to treat, especially in immunocompromised individuals. In the paper there are presented basic mechanisms of bacterial biofilm formation and the most important functions performed by the extracellular biofilm matrix (EPS). There were characterised main bacterial pathogens occurring in the industries such as: meat, dairy, fish, seafood, plantderived products with a minimum degree of processing, and in the juice branch; it was taken into account the possibility of those microorganisms to form a permanent and resistant to external factors biofilm. Also discussed were the possibilities of eradicating food biofilms with a particular emphasis on the methods based on the use of natural compounds of plant origin and the use of lytic bacteriophages and/or their purified enzymes.

Key words: bacterial biofilm, extracellular matrix, pathogens, biofilm elimination, food processing 